\title{
A New Colorimetric Assay for Determination of Selected Toxic Vapors and Liquids Permeation Through Barrier Materials Using the Minitest Device
}

\author{
PAVEL OTRISAL ${ }^{1 *}$, STANISLAV FLORUS ${ }^{1}$, LUBOMIR SVORC ${ }^{2}$, GHITA BARSAN ${ }^{3}$, DANUT MOSTEANU ${ }^{3}$ \\ ${ }^{1}$ Nuclear, Biological and Chemical Defence Institute of the University of Defence in Brno, Vita Nejedleho, 68201 Vyskov, Czech \\ Republic \\ IInstitute of Analytical Chemistry, Faculty of Chemical and Food Technology, Slovak University of Technology in Bratislava, \\ Radlinskeho 9, 81237 Bratislava, Slovak Republic \\ ${ }^{3}$ Land Forces Academy, 3-5 Revolutiei Str., 550170, Sibiu, Romania
}

\begin{abstract}
A moment of permeation of both gaseous and liquid phases of a toxic compound through a barrier material has been indicated colorimetrically at the same time on 20 exposed places using suitable colour indicators. The newly developed device MINITEST is able to evaluate the resistivity of both porous and non-porous barrier materials of a textile character against permeation of toxic vapours (permeation) and liquids (penetration) in static conditions. As a model test chemical either the sulfur mustard or significantly alkaline or acid volatile toxic compound have been applied. During the permeation, these species react with a suitable acid-base indicator and a markedly coloured stain can be created. Newly developed MINITEST device enables determination of chemical resistance of areal barrier materials not only in a process of their development but also in the rate of their practical applications.
\end{abstract}

Keywords: MINITEST, permeation, toxic compound, chemical warfare agent, indicator

Providing with high quality protection to Czech Army Forces (CAF) - Chemical Corps' specialists against the impact of a wide spectrum of threats (existing in all types of military operations) is a long-term challenge for all specialists dedicated to these researches from various branches. A multitude of activities during the production process of war equipment are continuously evaluated from the point of view of protection against chemical warfare agents (CWAs) - toxic substances (industrial chemicals (TICS), pharmaceuticals). Sometimes, such substances can be found in the environment as well, seriously affecting plants, animals, and human's health [1-8].

Because all the companies are concerned with the development and increase of production [9-15], they are carefully following the production process from product's conception to its final stage of life [13-21]. In the field of industrial production of materials / textile materials the existence of these control activities allows a permanent qualitative assessment of prospectively usable permeable materials whose application may be very interesting from the protection against chemicals viewpoint [18-29].

Filtration protection suits (FPS) designated for all armed forces protection of the soldiers' body surface against vapors and roughly dispersive aerosols of (CWAs) are mainly made of permeable constructive materials of textile character [30]. Besides, it restricts the permeation of a liquid phase of toxic compounds into an under-garment area of the protective garment. Likewise, the adsorption textile with decreased flammability based on active charcoal, such as a spherical or filamentous pow der, gives rise to the effective barrier against quick permeation of vapors of volatile toxic compounds (VOCs) to the user's body surface to be prevented. As carrier material for active charcoal either a nonwoven fabric or a thin layer $(2 \mathrm{~mm})$ of stabilized polyurethane (PUR) foam is most often used with the fixation of activated charcoal using suitable polymeric binders [31]. The spherical activate charcoal is anchored on a textile platform, rather using hot melt adhesives (e.g. SARATOGA) [32-34]. Lining consists of either a single structural layer or an integral part of the adsorption textile. It facilitates dressing, leads away sweat as well as increases the mechanical resistance of protective equipment. Filtration protective garment is usually constructed as a greatalternative of a field uniform, but it may also take the form of a disguise [35].

For quantitative permeation rate assessment of VOCs through protective garments materials, the methodologies for stationary chemical laboratories have been established in the CAF. These methodologies allow not only monitoring the vapor permeation through porous materials in dynamic conditions but also evaluating the rate of static permeation within the contamination of porous and non-porous materials by gaseous or liquid phase of CWAs or other VOCs [36]. The problem usually lies in the fact that these simple methods for the breakthrough time (BT) determination are suitable mainly for quick evaluation of barrier materials from non-porous polymeric layers. However, they are practically useless for determination of BT for porous materials of the textile character in which drops of the sulfur mustard are relatively easily soaked to be resulted in penetration instead of permeation.

On the basis of such knowledge and experience, the MINITEST assay enabling quick determination of sulfur mustard vapors permeation through textile materials of a FPS has been formerly developed. Its innovative arrangement has been expanded on the employment of other test chemicals. Basically, there are some chemical tests with the permeation of the vapors of tested material to be colorimetrically detected or, similarly to permeation of vapors of the sulfur mustard using a suitable acid-base (or another) indicator. 
The main advantage of the MINITEST embodies in the simplicity of the assay, minor requirements on equipment and material furnishing and the possibility of rapid statistical evaluation of the resulting BT obtained from 20 measuring points simultaneously. The MINITEST assay is designed primarily for examination of protective properties of the adsorption textiles or FPS material ensembles against permeation of selected CWAs and TICS.

The aim of this paper is to deal with simple technical device which is designated for quick assessment of chemical resistance of both porous and non-porous barrier materials used in individual and collective protection. Main advantage of the MINITEST devise lies in the simplicity of a construction setting and possibility of testing in conditions of field analyses without necessity of complicated laboratory equipment. A perspective of MINITEST assay consists in the possibility of usage of other types of indicators which enable to sensitively detect permeated amounts of test chemicals.

\section{Experimental part}

Material and method

The whole experimental set-up of the new MINITEST assay is illustrated in figure 1. Single functional parts of this set-up are demonstrated in figured 2.

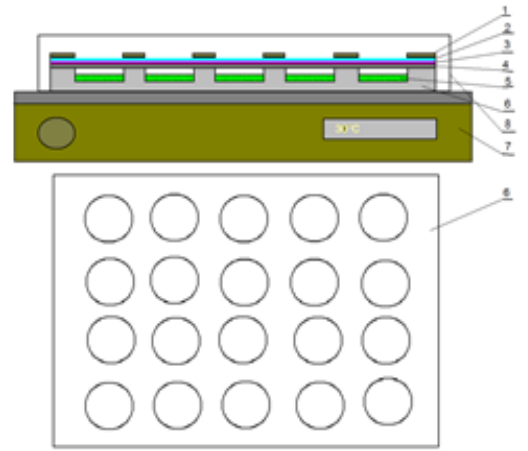

Fig. 1. The scheme for colorimetric assay of the MINITEST device during observation of the permeation of the sulfur mustard vapors through porous materials in static conditions: ( 1 - metal mask from the stainless steel, 2 - glass plate, 3 - indication layer, 4 - tested material, 5 - glass frit soaked with the test chemical $(0.5 \mathrm{~mL}), 6$ basic punched PVDF tested board (thickness $10 \mathrm{~mm}$ with holes for glass frits, 7 - plate thermoregulator, 8 - transparent plastic cover)
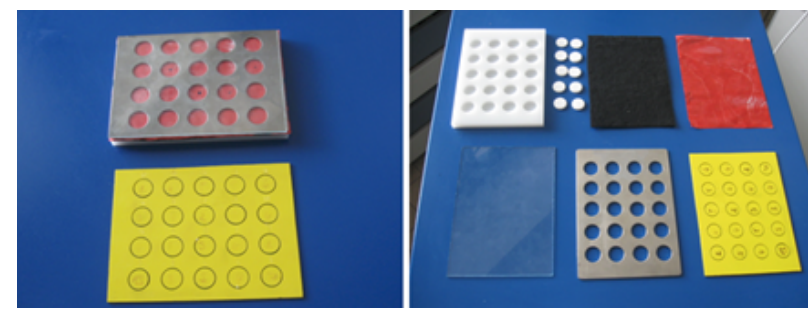

Fig. 2. Experimental set-up within the test and real appearance of single parts of the set including the plate for results recording

As it is evident from figures 1 and 2 the colorimetric assay consists on quite approachable and relatively cheap parts. Their production is not complicated. This makes this device very useful not only for laboratory but also for field conditions.

The basic punched PVDF board (fig. 1, position 6) with regularly distributed holes was put on the tempered areal source of the heat (position 7). Glass frits (position 5) were put into holes and the basic punched PVDF tested board was covered with the glass plate (position 2). Two circle cuts of the filtration paper from glass fibers can be used instead of glass frits.
This solution seems to be better when using real CWAs in order to avoid contamination.

The areal source of sulfur mustard vapors realized in the form of a glass porous tablet (frit) soaked with liquid phase of the sulfur mustard is located in the distance of 2-3 mm under the sample of the tested material with the dimensions of $130 \times 160 \mathrm{~mm}$. This platform is placed in 20 regularly located circle diffusion chambers with the diameter of $20 \mathrm{~mm}$ and depth of $6 \mathrm{~mm}$ drilled in PVDF (polyvinylidene fluoride) board with the thickness of 10 $\mathrm{mm}$. The saturated vapors of the sulfur mustard diffuse through the temperate sample vertically to its area against the direction of gravitation. The permeation of the threshold amount of these vapors is verified visually based on a color change of the special indication layer consisting of the textile or filtration paper with the neutral leach.

The layer is put on the sample. The glass plate with metal mask from the stainless steel (thickness of $2 \mathrm{~mm}$ ) with the same holes is put over the indication layer. The whole set is tempered on the required temperature (usually $30{ }^{\circ} \mathrm{C}$ ) using a plate thermoregulator and covered with a transparent plastic cover from the polyethylene foil.

After tempering the experimental set-up to the desired temperature $\left(30^{\circ} \mathrm{C}\right)$ the cover glass was removed and all porous glass frits were gradually wetted with $0.5 \mathrm{~mL}$ of sulfur mustard and subsequently quickly overlaid by sample of tested material with a preformed indication layer.

Finally, the whole set was covered with a cover glass, loaded by a metal mask with holes with the size and layout to be in good accordance with the position of area sources of mustard vapors. After completing the set-up was switched with clamps and covered with transparent plastic cover (position 8). When wetting glass frits with sulfur mustard it should be taken care of not to stain the basic punched PVDF tested board and sample of tested material.

Moment of starting material exposure to sulfur mustard vapors was considered to be the beginning of measurement BT (in the case of sulfur mustard also BTY). Breakthrough time of the sulfur mustards (BTY) was determined by formation of the first observable color spots of about 1 $\mathrm{mm}$ diameter on a pink background. A moment of permeation of sulfur mustard vapor with limit concentration (corresponding to BTY) through tested material (fig. 3) observed at each of the 20 designated circular surfaces was registered on a recording plate (fig. 4). The assay was terminated after recording the last observed permeation of the sulfur mustard vapors in the defined area of the sample.

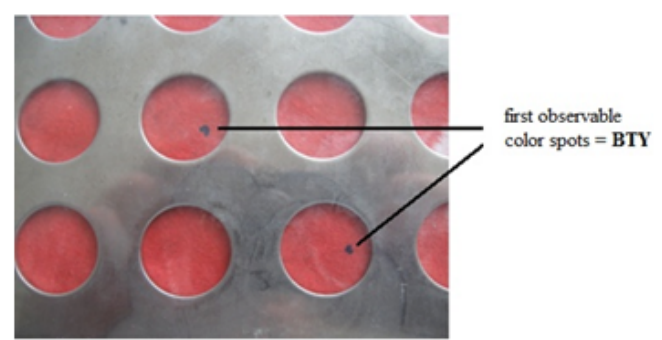

Fig. 3. The detail of the change of the indication layer in the moment of the sulfur mustard permeation corresponding to BTY

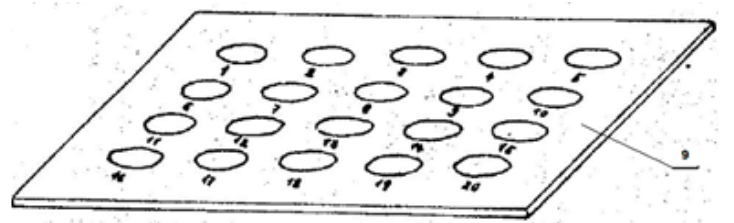

Fig. 4. The platform for results recording 


\begin{tabular}{|c|c|c|}
\hline \multirow[b]{2}{*}{ Test chemical/tested barrier material } & \multicolumn{2}{|c|}{ Barrier material } \\
\hline & $\begin{array}{c}\text { Porous } \\
\text { (permeable) }\end{array}$ & $\begin{array}{l}\text { Non-porous } \\
\text { (isolative) }\end{array}$ \\
\hline Acetic acid $99.8 \%$ - absolute, diluted by $1: 10(\mathrm{v} / \mathrm{v})$ with redistilled water & l & - \\
\hline Cyclohexylamine - absolute, diluted by $1: 10(\mathrm{v} / \mathrm{v})$ with redistilled water & 7 & - \\
\hline Piperidine - absolute, diluted by $1: 10$ (v/v) with redistilled water & T & - \\
\hline Benzylamine - absolute, diluted by $1: 10(\mathrm{v} / \mathrm{v})$ with diethanolamine & T & - \\
\hline Monoethanolamine - absolute & T & T \\
\hline ammonia & T & ? \\
\hline Chloroacetic acid $36 \%$ & T & T \\
\hline Acetic acid $99.8 \%-$ absolute & - & T \\
\hline Cyclohexylamine - absolute & - & ? \\
\hline Piperidine - absolute & - & T \\
\hline Benzylamine - absolute & - & T \\
\hline Iodine $(0.1 \mathrm{~g}$, crystalline form $)$ & ? & ? \\
\hline
\end{tabular}

Table 1

THE OVERVIEW OF SUITABLE MODEL TEST CHEMICALS FOR TESTED BARRIER

MATERIALS
In the case that the measurements are still running, the new sample of the tested material is put on the basic punched PVDF tested board and the similar procedure as mentioned above can be undertaken. This approach enables users to spare CWAs and to maximally use formed conditions for real measurements especially during a comparison of s bigger number of tested samples of barrier materials.

After the assay termination the transparent plastic cover was taken down (position 8), and the metal mask from the stainless steel was removed (position 1). The glass plate was rinsed with ethanol which was necessary to be caught in a glass bowl for contaminated waste. The glass plate was put into a jack after that.

Contaminated sample of the tested material (position 4) with the indication layer (position 3) was laid down into the bowl for contaminated waste in which a decontamination mixture solution was occurred. After the total assay termination the plate thermoregulator was switched off and the transparent plastic cover was removed.

During the whole measurement activities strict regulations must be kept due to manipulating with CWAs or acids. All used staff must be either carefully decontaminated or liquidated.

Principally, the same set-up of the MINITEST device was kept within the determination of selected TICs permeation. The procedure of testing was the practically same as in the case of the sulfur mustard. The change embodied in the fact that instead of the sulfur mustard the selected acid or alkalic volatile TICs were used. The main condition was that their vapors were detectable with the using violent color change of diverse acid-base indicator or another type of the indicator (table 1).

\section{Results and discussions}

If we use this procedure of preparation of detection layers for determination of permeation of basic vapors of TICs We have to cut a rectangle $130 \times 180 \mathrm{~mm}$ of the filtration paper with the neutral leach to be put on a glass plate using cover with a metal mask with 20 holes. Afterwards, one drop (approximately $5-10 \mu \mathrm{L}$ ) of $0.1 \%$ solution of phenolphtalein in ethanol was dropped into the middle of each hole. The formed detection layer was dried on the plate thermoregulator in $40{ }^{\circ} \mathrm{C}$ for $10 \mathrm{~min}$. The prepared detection layer was then keptin a gas-tightcover. Within the assay we observed the color transition in purple coloration. The color change and a character of permeation are apparent from figure 5 .

We followed the same procedure as in the case mentioned above. The difference consisted in the indicator to be used, while in this case $0.1 \%$ ethanol solution of methyl red was applied and the color transition from yellow to

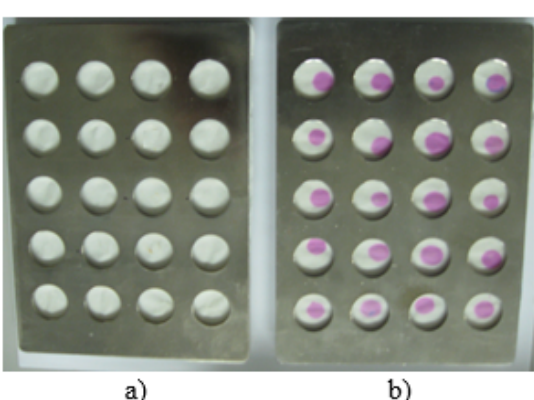

Fig. 5. The appearance of detection layer before (a) and after (b) permeation of assay chemical through tested material

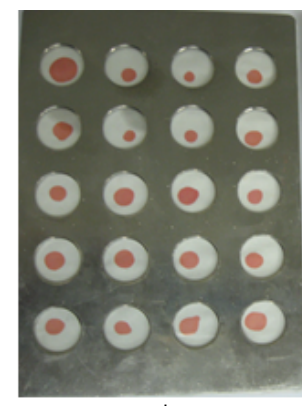

a)

\section{b)}

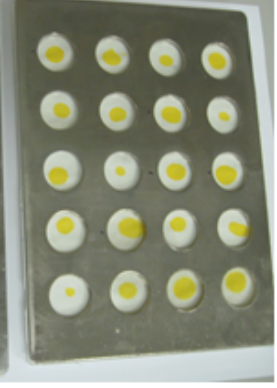

b) dark red coloration was noticed. The color change and the character of permeation are evident from figure 6 .

From both figure 5 and 6 it is evident that the amount of permeated chemicals in not the same. Moreover, it is visible that used barrier materials are not homogenous from different reasons such as different amount of the active charcoal which can caused diverse sorption of the test chemical, various thickness of materials and so on.

These results can be quite simply described by an operator just after performed measurements and they can be simultaneously used for making recommendations how to enhance the particular materials on better level from the protective properties point of view.

\section{Conclusions}

The MINITEST device constitutes a simple, unique and effective tool for superfast determination of resistivity of textile and rubber barrier materials related to permeation and penetration of toxic compounds of interest. The possibility of combination of an approach based on determination of used properties in relation to CWAs and selected TICs enables the real viability of this device.

\section{References}

1.PANAITESCU, C., J INESCU, C., MARES, A.M., Rev. Chim.(Bucharest), 67, no. 5, 2016, p. 925.

2.TASCHINA, M., COPOLOVICI, D.M., BUNGAU S., LUPITU, A.I., COPOLOVICI, L., IOVAN, C., Farmacia, 65, nr. 5, 2017, p. 709.

3.CARAC, A., BOSCENCU, R., DEDIU, A. V., BUNGAU S. G., DINICA R. M., Rev. Chim.(Bucharest), 68, no. 7, 2017, p. 1423. 
4.COPOLOVICI, L., TIMIS, D., TASCHINA, M., COPOLOVICI, D., CIOCA, G., BUNGAU S., Rev. Chim.(Bucharest), 68, no. 9, 2017, p. 2076. 5.BUNGAU, S., SUCIU, R., BUMBU, A., CIOCA, G., TIT, D.M., J. Environ. Prot. Ecol., 16, nr. 3, 2015, p. 980.

6.TIT, D.M., BUNGAU, S., NISTOR CSEPPENTO, C., COPOLOVICI, D.M., BUHAS, C., J. Environ. Prot. Ecol., 17, nr. 4, 2016, p. 1425. 7.POPESCU, D.E., BUNGAU, C., PRADA, M., DOMUTA, C., BUNGAU, S., TIT, D.M., J. Environ. Prot. Ecol., 17, nr. 3, 2016, p. 1011.

8.IONESCU, G., RADA, E.C., CIOCA, L.-I., Environ. Eng. Manag. J., 14, nr. 11, 2015, p. 2537.

9.BUnGAU, C., BLAGA, F., GHERGHEA, C., Proceedings of the 2nd Review of Management and Economic Engineering Management Conference: Management of Crisis or Crisis of Management?, Cluj Napoca, Romania, 2011, p. 36.

10.CUC, S., BUNGAU C., Management between profit and social responsibility, Review of Management and Economic Engineering International Management Conference, Cluj Napoca, Romania, 2014, p. 186.

11.CUC, S., TRIPA, S., BUNGAU, C., 5th Review of Management and Economic Engineering International Management Conference, Cluj Napoca, Romania, 2016, p. 100-+.

12.BUNGAU, C., GHERGHEA, I.C., PRICHICl, M., Twenty Years after: How Management Theory Works, Proceedings, Review of Management and Economic Engineering International Management Conference, Cluj-Napoca, Romania, 2010, p. 188.

13.IVASCU, L., CIOCA, L.-I., Advances in Education, 2nd International Conference on Psychology, Management and Social Science, Shenzhen, China, 49, 2014, p. 77.

14.BADULESCU, D, BUNGAU, C., BADULESCU, A., J. Environ. Prot. Ecol., 16, nr. 3, 2015, p. 1101.

15.CIOCA, G., BACAITA, E.S., AGOP, M., LUPASCU URSULESCU, C., Comput. Math. Methods Med., art. no. 5748273, 2017, 8 pages.

16.BUNGAU, C., BLAGA, F., GHERGHEA, C., 2014 International Conference on Production Research - Regional Conference Africa, Europe and the Middle East and 3rd International Conference on Quality and Innovation in Engineering and Management, Cluj-Napoca, Romania, 2014, p. 55.

17.CSOKMAI, L.S.,TARCA, R.C., BUNGAU, C., HUSI, G., Int. J . Comput. Commun. Control, 10, nr. 1, 2015, p. 30.

18.BUNGAU, S., BUNGAU, C., TIT, D.M., J. Environ. Prot. Ecol., 16, nr. 1, 2015, p. 56.

19.MOSTEANU, D., TREFAS, L., TREFAS, A.-S., MOSTEANU, R., The 21st International Conference Knowledge Based Organization, Nicolae Balcescu Land Forces Academy, Sibiu, Romania, 2015, p. 209.
20.GIURGIU, L., BARSAN, G., MOSTEANU, D., The 9th International Management Conference: Management and Innovation For Competitive Advantage, Bucharest, Romania, 2015, p. 506.

21.MOSTEANU D., HALMAGHI, E.E., 18th International Conference - The Knowledge-Based Organization: Management and Military Sciences, Conference Proceedings 1, Sibiu, Romania, 2012, p. 548.

22.RADU, C.D., DANILA, A., SANDU, I., MURESAN, I.E., SANDU, I.G., BRANISTEANU, E.D., Rev. Chim.(Bucharest), 68, no. 6, 2017, p. 1345. 23.PARTENI, O., RADU, C.D., MURESAN, A., SANDU, A.V., OPROIU, L.C., CIOBANU, L., SANDU, I.G., Rev. Chim.(Bucharest), 66, no. 11, 2015, p. 1780.

24.STANESCU, M.D., FOGORASI, M., DOCHIA, M., MIHUTA, S., LOZINSKY, V.I., Rev. Chim.(Bucharest), 60, no. 1, 2009, p. 59.

25.TULBURE, E.A., SANDU, I.G., ATODIRESEI, G.V., SANDU, I., Rev. Chim.(Bucharest), 64, no. 7, 2013, p. 736.

26.IORGOAIEA, G.M., CAMPAGNE, C., GIRAUD, S., BREBU, M., VRINCEANU, N., CIOCA, L.I., J. Textile Institute, 106, nr. 2, 2015, p. 119.

27.VLAD, D., CIOCA, L.I., 10th International Conference Interdisciplinarity in Engineering, INTER-ENG 2016, Procedia Engineering, Tirgu Mures, Romania, 181, 2017, p. 324.

28.VLAD, D., CIOCA, L.I., $9^{\text {th }}$ International Conference Interdisciplinarity in Engineering, INTER-ENG 2015, Procedia Technology, Tirgu Mures, Romania, 22, 2016, p. 60.

29.LI, P., LIANG, J., SHEN, X., SHEN, X., ZHAO, M., SUI, L., Multimed. Tools Appl., 2017, https://doi.org/10.1007/s11042-017-5263-Z.

30.CHEN, X., Advanced Fibrous Composite Materials for Ballistic Protection, 1st ed., Cambridge: Elsevier Woodhead Publishing Limited, 2016.

31.CHERIF, C., Textile Materials for Lightweight Constructions: Technologies-Methods-Materials-Properties, 1st ed., Dresden: Springer, 2016.

32.HARRO, T., New Materials Permeable to Water Vapor, 1st ed., Leverkusen: Springer, 1999.

33.SEN, A.K., Coated Textiles., 2nd ed., Boca Raton: CRC Press, 2008. 34.BANSAL, R.C., GOYAL, M., Activated Carbon Adsorption, 1st ed., Boca Raton: CRC Tyalor \& Francis, 2005.

35.RAHEEL, M., Modern Textile Characterisation Methods., 2nd ed., New York: Marcel Dekker, 1996.

36.PERKINS, J.L., STULL, J.O., Chemical Protective Clothing Performance in Chemical Emergency Response, 1sted., Philadelphia: ASTM, 1989

Manuscript received: 17.08 .2017 